Arhe XVI, 31/2019

UDK 1:070

DOI https://doi.org/10.19090/arhe.2019.31.275-290

Originalni naučni rad

Original Scientific Article

\author{
MILAN VUKADINOVIĆ ${ }^{1}$ \\ Univerzitet u Novom Sadu, Filozofski fakultet
}

\title{
NEUROFILOZOFIJA I DRUŠTVENI MEDIJI: PREPLITANJA KOMPLEKSNIH MREŽA ${ }^{2}$
}

\begin{abstract}
Sažetak: Neuronaučni progres tokom proteklih nekoliko decenija ne samo da je postepeno razotkrio ljudski mozak kao „društveni organ“ koji je evoluirao da se poveže sa drugim mozgovima, već je takođe podstakao mogućnosti šireg neurofilozofskog pristupa sferi savremenih društvenih fenomena kao što je povećavanje ljudske interakcije na društvenim medijima omogućene novim digitalnim tehnologijama. $\mathrm{Ne}$ samo da bi neurofilozofija mogla da obezbedi empirijsku osnovu za objektivnije razmatranje složenih egzistencijalnih, kulturnih, političkih i etičkih aspekata ljudskog društva na aktuelnom stupnju globalne međupovezanosti, već bi i neki od pristupa s anti-redukcionističkog kraja spektra „bihejvioralnih i moždanih nauka“ (kao što su teorije haotičnih ili emergentnih dinamičkih sistema) mogli biti korisni u istraživanju kompleksnih mreža društvene interakcije koje bi mogle imati bitne efekte na jačanje demokratskih pojava poput „mudrosti gomila“, samoniklih „grasruts“ inicijativa ili plišanih revolucija.
\end{abstract}

Ključne reči: neurofilozofija, društveni mediji, kognitivna nauka, haotične kompleksne mreže, mudrost gomila

\section{NEUROFILOZOFIJA, KOGNITIVNA REVOLUCIJA I DRUŠTVENI MEDIJI}

Najmanji zajednički imenitelj demokratizacije korišćenja digitalnih medijskih tehnologija i prodora savremenih neuronaučnih

\footnotetext{
${ }^{1}$ E-mail adresa autora: vukadinovic.milan838@gmail.com

${ }^{2}$ Ovaj rad je deo naučno-istraživačkog projekta Digitalne medijske tehnologije $i$ društveno-obrazovne promene, koji finansira Ministarstvo prosvete, nauke i tehnološkog razvoja.
} 
iskoraka u fokus šireg društvenog interesovanja, mogao bi se istorijski slediti do sredine 20. veka, odnosno intelektualnog zamaha tzv. „kognitivne revolucije“: obračun psihologije i lingvistike sa problemom „oskudnosti stimulusa“ naspram raskošne palete ljudskog verbalnog ponašanja, uslovio je zaokret od empirijskih ispitivanja adaptivnih navika ka formalnoj rekonstrukciji „obrnutog inženjerstva“ urođenih kognitivnih funkcija, koje determinišu odlike ljudskog jezika, percepcije, memorije, reprezentacije, koordinacije akcija i samo-kontrole, sprovodivoj paralelno sa konstruktivnim iznalaženjem sve efektivnijih algoritmičkih procedura i serija računskih operacija unutar novih oblasti tehničkih istraživanja poput veštačke inteligencije i kompjuterske nauke - univerzalne principe na osnovu kojih bi i sam mogao biti ,programiran“ da funkcioniše, čovek je hteo da izuči u celom spektru prirodnih nivoa tj. medija realizacije, kroz raznolike vidove „obrade informacija“ $u$ biološkim i mašinskim sistemima (Pinker 2003: 31-32). ${ }^{3}$

${ }^{3}$ Teorema Kurta Gedela o nemogućnosti redukovanja matematičkih na logičke istine, koja je utvrdila da se za svaki sistem polaznih logičkih aksioma čisto formalnim putem može pokazati tačnost paradoksalnog iskaza kojim se tvrdi upravo nedokazivost samog tog iskaza unutar datog sistema - zbog čega se javlja mogućnost da matematički iskaz u isti mah bude tačan i logički nedokaziv (na ekvivalentan način kao što kod paradoksa lažljivca u kome neki Krićanin tvrdi da „svi Krićani uvek lažu“, nije moguće obrazložiti što bi u nekoj fazi bilo opravdano stopirati tok rezonovanja, opredeliti se za to da li je iskaz istinit ili lažan i tako prosto ,izaći iz začaranog kruga“), podstakla je Alana Tjuringa na konkretizaciju te linije rezonovanja u području teorije izračunljivosti, kroz pokazivanje nemogućnosti rešenja za tzv. „problem zaustavljanja“ hipotetičkog automata pri izvršenju opisanog tipa algoritma koji upućuje sam na sebe. Datu problematiku „autoreferencije“ ili „rekurzije“, popularizovao je Daglas Hofštadter kroz filigransku eksplikaciju bazičnog fenomena koji se na izomorfne načine javlja unutar Gedelove teoreme nepotpunosti aksiomatskih sistema, Ešerove grafike uzajamno crtajućih ruku i Bahovog rakovog kanona usklađenog za čitanje i odnapred i odnatrag (ali i Zenonove aporije „trke Ahila i kornjače na $111,1 \ldots \mathrm{m}^{\text {“) }}$, kako bi kroz pojam ,čudne petlje“ - hijerarhijskog sistema koji u paradoksalno cikličnom maniru „napreduje ka početku“ - mogao izvesti analogiju sa „povratnim strukturama“ kojima iz „,nesvesne biološke materije“ iskrsava „svesno psihološko Ja“ (Hofstadter 1979: 32- 36). (te ideje našle su 
Reformu transdisciplinarnih pristupa etabliranih na MIT-u poput teorije sistema i kibernetike - Noam Čomski inicirao je u polju lingvistike zasnivanjem transformaciono-generativne gramatike bazirane na konteksno slobodnim sintaktičkim strukturama tj. univerzalnim pravilima čovekovog ,unutrašnjeg operisanja simbolima“, koje prosečne jedinke homo sapiens-a aktiviraju u kontaktu sa bilo kojim jezikom svoje vrste i „ospoljavaju“ prema njegovim varijabilnim karakteristikama (što npr. dopušta detetu iz Papua Nove Gvineje, koje desetinama hiljada godina nije imalo dodira sa genofondom ostatka ljudske populacije, da otputuje na Harvard i bez teškoća nauči engleski - poduhvat neostvariv uz bilo kakve napore mladunaca druge vrste na bazi pokušaja i pogrešaka), ${ }^{4}$ čime je pružio i doprinos izdvajanju ljudskog jezika od sistema komunikacije drugih organizama fokusiranih na razmenu podataka iz okoline (objašnjavanu pojmovima ranije teorije informacija Kloda Šenona - signala, šuma, kanala i poruke), po njegovoj povratnoj usmerenosti na sopstveni „unutrašnji monolog“, tj. okrenutosti prema apstraktnim misaonim proračunima i predviđanjima. Međutim, upućenost kognitivne nauke ka tumačenju odnosa ljudskih mentalnih i fizičkih

primenu i na kognitivnom modelu „Copycat“ - izrađenom za „paralelne“ analogijske procese tj. svu aproksimativnu, metaforičku ili komparativnu „rezonanciju“ ljudskih neuronskih mreža).

${ }^{4}$ Primerom svoje čuvene rečenice „Bezbojne zelene ideje besno spavaju“ („Colorless green ideas sleep furiously“), Čomski je želeo pokazati da semantički besmislena rečenica bez problema može biti sintaktički ispravno formirana (u pogledu „subjekatsko-predikatske strukture“, zbog čega bi mogla biti podvrgnuta standardnim ,transformacijama“ - npr. putem njenog prevođenja u oblik pitanja), ali i da zanemarljiva statistička verovatnoća da je takva rečenica ikada do tada bila formirana, nameće zaključak da se ,gramatičnost“ te rečenice mora zasnivati na „generativnosti“ čovekovog jezika tj. njemu urođenoj kreativnoj sposobnosti da na bazi ograničenog broja pravila slobodno formira neograničen broj novih rečenica tako da one budu odgovarajuće za odredbu situacije, a ne samo puki odgovor na nju (Chomsky 1957: 15). Suprotnu stranu mogućnosti pragmatičkog poigravanja interpretacijama „mentalnih tipfelera“, kasnije je u filozofiji jezika proslavio Donald Dejvidson člankom „Lep deranžman epitafa“ (tj. ,,aranžman epiteta“). 
procesa po analogiji sa odnosom softvera i hardvera digitalnih kompjutera (npr. „višestruke ostvarivosti“ aplikacija na raznovrsnim uređajima koji ih ,podržavaju“), dovedena je u pitanje sa nastupanjem dužih perioda „zime“ upravo na polju veštačke inteligencije: fokus na izradi neuronskih mreža za simuliranje apstraktnih (simboličkih) kognitivnih procesa koje je isprva etablirao Marvin Minski, u skladu s prognozama hajdegerijanskih filozofa tehnike poput Hjuberta Drajfusa izmeštan je ka ispitivanju konkretnih (indeksičkih/ikoničkih) kognitivnih procesa, njihove realne otelotvorenosti u prostoru i vremenu, kao i dinamične kontekstualne interakcije i sprege sa okruženjem u kome se odvijaju - umesto daljeg usložnjavanja okvira „kognitivnih arhitektura“, težište novih pristupa usmerenih odozdo-nagore pomeralo se ka modeliranju prostijih pojava poput navigacije insekata.

Uporedo sa opisanim tendencijama, Oksfordska škola „filozofije običnog jezika“ ne samo da je revitalizovala empirijska ispitivanja konteksta ljudskog delovanja kroz verbalnu interakciju - čije je epohalne odjeke moguće sumirati i krilaticom komunikativne teorije Maršala Makluana da je i sam „medij poruka“ (shodno nepojmljivosti bilo koje „arhimedovske tačke“ izvan jezika) - nego je kroz delo Gilberta Rajla postavila i osnove anti-dualističke orijentacije filozofije duha (tj. kritike dekartovske kategorije „duha u mašini ljudskog tela“ i isticanja identiteta/kontinuiteta mentalnih i fizčkih aktivnosti/predikata, npr. „događaja na univerzitetu i u njegovom kampusu“), pri čemu je s ubrzanim progresom tehnologija skeniranja njen akcenat sve više pomeran u smeru neuronaučnih asumpcija da „um jeste ono što mozak radi“.5 Ali do novog pragmatičkog zaokreta od jezičkog ka

5 Komplementarna primena „direktnih“ elektrofizioloških (npr. EEG) i „indirektnih“ hemodinamičkih (npr. $f M R I$ ) formula za neurovizuelizaciju (zavisno od toga da li je, recimo, prioritet vremenska ili prostorna rezolucija snimaka) omogućila je detaljnija empirijska ispitivanja „teorija psihoneuralnih identiteta“: dok je npr. identifikacija oseta bola sa nadraživanjem C- i A-deltavlakana osporena potvrđivanjem aktivacije odgovarajućih centara korteksa i talamusa pri „fantomskim bolovima“" u amputiranim udovima, poistovećivanje evociranih električnih potencijala P600 i N400 (van Vernikeove zone) sa 
neuronaučnom pristupu dospeva se tek pod uticajem trendova u filozofiji nauke: artikulisanje vizije „mrežnog preplitanja“ filozofskog i naučnog znanja od strane Vilarda Kvajna, distingviranje „manifestne i naučne slike sveta“ (npr. „misli i čestica“) od strane Vilfrida Selarsa, isticanje značaja faza diskontinuiteta u promenama naučnih paradigmi od strane Tomasa Kuna, ili viđenje empirijske opovrgljivosti teorija kao uslova njihove naučnosti od strane Karla Popera samo su neke od doktrina koje su trasirale intelektualni kurs Pola i Patriše Čerčland kao pionira „neurofilozofije“ - pri tom je razvoj eliminativnog materijalizma kao njene dominantne pozicije podstican i epistemološkim anarhizmom Pola Fajerabenda, ali i pesimizmom Ričarda Rortija oko iznalaženja odnosa referencije mentalnih i fizičkih vokabulara (sličnih npr. „Zevsu i grmljevini“").

Neurofilozofija kao oblast usmerena ka istraživanju mogućih implikacija neuronauke na tradicionalna filozofska pitanja ljudskog postojanja, saznanja, jezika, vrednosti ili slobode volje (npr. neuroloških dijagnoza bipolarnih sindroma na filozofski problem jedinstvenog subjekta), uz strategiju „koevolucije“ interdisciplinarnog rada na raznim nivoima (Churchland P. S. 1986: 297) sprovodila je i kritike ranijih gledišta poput „višestruke ostvarivosti“", usled paušalnog shvatanja korelacije između preširoko definisanih kognitivnih stanja i preusko definisanih neuralnih stanja, (npr. ,apstraktnog koncepta memorije“ i „konkretnog procesa dugotrajne potencijacije neurona“), „nesvodivosti subjektivnih kvalia na objektivne uzroke“ (npr. „crvenila na efekte fotoreceptora"), naočigled vidne apsurdnosti identičnog poricanja mogućnosti svođenja optičkog pojma svetla na elektromagnetno zračenje određenog talasnog opsega, ili pak „među-teorijske redukcije“, u vezi sa uvidom da - suprotno datom slučaju pojma svetla, gde je utvrđen ,međuteorijski identitet" - većinu psiholoških teorija zapravo iščekuje prosto eliminisanje iz vokabulara buduće neuronauke (kao npr. u slučaju flogistona, za koji su hemičari mislili da materijali otpuštaju pri sagorevanju, dok nisu uvideli da se čitav proces odvija u kontra-smeru,

sintaktičkom i semantičkom obradom verbalnog stimulusa pokazalo se vrlo obećavajućim. 
kao i da se tada eksploatiše kiseonik). Eliminativni materijalizam kao neurofilozofska pozicija zastupa tezu da „popularnu psihologiju“ shvaćenu u najširem smislu zdravorazumskih „propozicionih stavova“ (namera/želja/strahova), ali i čitave „mentalne paučine“ rituala, mitova, religija i filozofija - čeka zamena potkrepljenim objašnjenjima neuronaučnih teorija (a što bi omogućilo i jasnije razdvajanje patoloških situacija od međuljudskog razumevanja, koje bi i nakon toga zadržalo značaj - slično ulozi ljudskog srca u ,simbolici ljubavi“): sama čovekova nemogućnost da potpuno razgraniči neposredno iskustvo od njegove diskutabilne jezičke interpretacije (što se npr. može jasno ilustrovati u slučaju razlike u postupku raspoznavanja vrste drveta od strane laika koji se „trudi da se priseti“ i stolara koji je „već unapred spontano vidi“), ostavlja ga, pak, u položaju sličnom vrlo malom detetu (ili kučetu) koje, recimo, ima određenu „,nameru vezanu za dolaženje do mleka u frižideru“, premda nema ni približnu predstavu o tome šta objektivno predstavljaju „mleko“ i „frižider“, budući da ne barata pojmovnom alfabetom neophodnim za bazičnu sliku o njima. Diskretne operacije „logičkih kola“ popularne psihologije nad „propozicionim sadržajima“ (npr. kada premise „Svi ljudi su smrtni“ i „Sokrat je čovek“ nužno impliciraju zaključak „Sokrat je smrtan“) Pol Čerčland stoga zamenjuje „fluksom“ kompjutacionih operacija primerenim kapacitetu mozga da „šifruje“ informacije kroz različite intenzitete aktivacije neurona (analogno tome kao što su vizuelne informacije na ekranu kodirane u različitim intenzitetima aktivacije piksela), pa bi tako evolucija „obrazaca aktivnosti“ neuronskih mreža očito mogla biti tumačena $\mathrm{u}$ vidu kognitivne procedure, kada oni istovremeno: a) formiraju sistem koji donekle korespondira s relevantnim distinkcijama u spoljnom okruženju b) nisu generisani kroz senzorni input, već nakon njegove obrade tj. „vektorske transformacije“ (npr. promena „sinaptičkih težina“ vezanih za stepen otpuštanja presinaptičkih neurotransmitera, brojnost i efikasnost postsinaptičkih receptora ili pak dostupnost enzima u sinaptičkoj pukotini) i c) omogućuju neuronskoj mreži da kroz motorni autput reaguje uz kontinuiranu redukciju greške (bilo zahvaljujući biološkim adaptivnim korekcijama, bilo pak veštačkim algoritmima za učenje, kao presudnoj specifičnosti u rasponu 
„od amebe do Ajnštajna“) - zbog čega i nove kombinacije obrazaca aktivnosti, koje inoviraju čovekov sistem pojmova ili teorija o svetu, ${ }^{6}$ prosto odražavaju ažuriranje konfiguracija sinaptičkih težina u cilju boljeg predviđanja i prilagođavanja okruženju širenjem obima „imitacionih repertoara i kreativnih potencijala“ (Churchland P. M. 1989: 61-64).

Ukoliko se pak pažnja preusmeri na medijsko-teorijske crte razvoja ljudske komunikacije tokom proteklog veka - od ranijih štampanih i elektronskih, do internetskih društvenih medija - jedan od središnjih problema u razumevanju osobenosti novih digitalnih tendencija iskazuje se u dilemi o baziranju komparativnog polazišta na sličnostima ili razlikama oflajn i onlajn aktivnosti, usled čega bi se i dalo naslutiti zašto bi neurofilozofski pristup njihovom istraživanju mogao biti učinjen plodotvornim: na sličan način kao u slučaju prethodno razmatrane problematike odnosa fizičkih i mentalnih procesa, za očekivati je da teorijska argumentacija i hipotetička obrazloženja bivaju potiskivani ili „transkribovani“ na ravni čvrsto utemeljenih nalaza empirijske neuronauke, koji bi mogli egzaktno ustanoviti karakteristične profile komunikativnih potreba savremene epohe (Meshi, Tamir \& Heekenen 2015: 771-773). Kritike internet platformi ranijih decenija kao što su BBS-ovi, veb forumi i čet sobe, isticale su problematičnost simulirane „hiperrealnosti“ u kojoj se konkretni personalni identiteti obesmišljavaju kroz idealizovane apstrakcije „virtuelnih avatara“, ali i odsustva svih neposrednih rizika $i$ produktivnih tenzija stvarnog egzistencijalnog angažmana koje biva kompenzovano potrebom za teatralnim eksperimentisanjem sa insceniranim narativima iza sigurnog paravana realne anonimnosti (Dreyfus 2001: 105). Međutim, eksponencijalni prodor novijih generacija društvenih medija poput Fejsbuka, Tvitera ili Snepčeta (praćen i zaokretanjem fokusa ka merama „sajber bezbednosti“ korisničkih identiteta i sadržaja), pružio je dodatni motiv za

\footnotetext{
${ }^{6}$ Kao što je npr. kombinacija koncepata mobilnih uređaja i interneta iznedrila inovaciju „mobilnih internet uređaja“. (Okvir „teorije mentalnih fajlova“ dopušta i nova formatiranja odnosa dinamike i indeksičke referencije koncepata.)
} 
neurofilozofskim rasvetljavanjem sve tešnje isprepletenosti oflajn i onlajn aktivnosti, ne samo usled gravitiranja digitalnog sveta prema svakodnevnom životu ${ }^{7}$ (ili njegove protetičke funkcije u sklopu „augmentovane realnosti“"), već i uporednog redefinisanja tekstura globalne javne sfere i njenih delikatnih egzistencijalnih, kulturnih, političkih i etičkih razmatranja savremenog društva, shodno dramatici viralnih polemičkih „rolerkostera“ - urgirajući time i za reorijentaciju nauke ka univerzalnim parametrima ljudske komunikacije na aktuelnom stupnju planetarne umreženosti. Relevantni neurofilozofski prilozi naučnom istraživanju društvenih medija, tako bi se mogli ticati prepoznavanja čovekovog mozga kao „društvenog organa“ koji je evoluirao da uspostavi vezu sa drugim mozgovima ${ }^{8}$ - delimično i zahvaljujući otkrivanju „neurona-ogledala“ (osobenih po tome što se aktiviraju i pri posmatranju, kao i izvođenju određenih radnji), a čije se uloge mogu tražiti u širokom rasponu od učenja jezika do emocionalne saosećajnosti; uticaja koncentracije hormona oksitocina na šablone ponašanja kojima se iskazuju ljubav, briga, zajedništvo i poverenje (kako u okviru porodice, tako i npr. odnosu ljudi sa psima i mačkama, nasuprot - i na internetu upadljivo manje zastupljenim - vukovima i

\footnotetext{
${ }^{7}$ Npr. upotrebe Forskvera za označavanje lokacija i Periskopa za video prenose (ali i svih panoptičkih data-centara).

${ }^{8}$ I oblasti poput matematičke teorije beskonačnih skupova Georga Kantora ili logike mogućih svetova Sola Kripkea, morale bi se u svetlu ljudskih bioloških limita načelno svrstati pod domen naučno isplative „društvene konstrukcije“. No, polja egzaktnih nauka poput teorije grafova, osim primena kod telekomunikacija ili epidemiologije, zasigurno bi mogla igrati ulogu i u paralelnom ispitivanju dinamike neuronskih i društvenih mreža (Basset \& Sporns 2017: 353). Demarkacija nivoa analize ipak se u neurofilozofiji iskazuje upitnom i na metaravni: njen kanonski primer izvesnog „društva koje isprva nije imalo mentalne pojmove, već ih je razvijalo kao interne opise predviđanja fizičkih procesa“ (pa bi npr. svi mogli verovati $i$ da toplotu neposredno iskušavaju u jedinicama opovrgnute teorije kalorijskih fluida), opstaje ili pada s ocenom prigovora da suspendovanje svih „društvenih mnjenja“ po uzoru na drevne predstave kako „sunce uveče tone u more“, nije pandan očitom poricanju nepostojećih relacija, nego same egzistencije sunca i mora.
} 
tigrovima); efekata neurotransmitera dopamina u nagrađivanju, a samim time i odlučivanju kao procesu ,realizacije najbolje strategije eliminisanjem alternativa“ (pri tom se oslobađanje supstance odvija tokom svih etapa planiranja i iščekivanja ishoda), dok njegova nesvodivost na automatski model „stimulusa i responsa“ dopušta i mogućnost da ljudima bude pripisana izvesna lična autonomija i moralna odgovornost za svoje postupke (Tagard 2014: 178, 217 i 262) pa ipak se generalno može konstatovati da se mozak kao dinamični kompleks interakcija materijala, signala i komponenata, poput samih društvenih medija ne odlikuje previše centralizovanom kontrolnom strukturom tj. da je neuporedivo manje nalik simfonijskom orkestru sa jednim dirigentom, nego blago haotičnom džez ansamblu, čija magija proističe upravo iz toga što svaki muzičar vuče na svoju stranu i održava „lokalnu koheziju“ putem učene improvizacije. ${ }^{9}$

\section{TEORIJA HAOSA, EMERGENTNI SISTEMI I KOMPLEKSNOST DRUŠTVENIH MEDIJA}

Pragmatička usmerenost neurofilozofije prema izvođenju implikacija iz celokupne palete „bihejvioralnih i moždanih nauka“ koja može sezati u rasponu od teorije evolucije i etologije, preko genetike i perinatologije, do neposrednih empirijskih opita endokrinologije i neuronauke ${ }^{10}$ - pri holističkom izučavanju kompleksne prespojenosti „konektoma“ mozga, imala bi i benefita od uvida iz oblasti sa anti-redukcionističkog kraja spektra pomenutih nauka, poput teorija haosa i emergentnih dinamičkih sistema, naročito

\footnotetext{
${ }^{9}$ Kraj ljudskog života (akustički stilizovan kao ,izmeštanje iz carstva muzike u carstvo tišine“) komplikuje se pritom i u digitalnoj i u realnoj sferi odnosa kliničke i pravne smrti - pomeranjima granica ,medicinski nepovratnih stanja“.

$10 \mathrm{Uz}$ celu lepezu aktuelnih „neurohumanističkih“ disciplina, od neurohermeneutičkog ispitivanja ,predrazumevanja“ kao ,prediktivne aktivnosti neuronskih mreža“ i neuroteoloških pregleda „stanja mozga pri ekstatičnim iskustvima“, do neuroestetičkih studija „multimodalne reprezentacije lepog“ i neuromarketinških testova „reakcija na brendove“ .
} 
kada se ima na umu potencijalni neksus sa prethodno elaboriranim trendom usložnjavanja komunikativnih navika usled ekspanzije društvenih medija. Ubrzan progres digitalnih tehnologija i kompjuterskih performansi najpre je unutar meteorologije dozvolio Edvardu Lorencu da kombinatoričkom igrom varijablama modela vremenske prognoze, utvrdi kako se i minimalna izmena vrednosti pete decimale ekspresno odražava na ukupno stanje, čime je iniciran nastanak teorije haosa - okrenute ispitivanju ,nelinearnih dinamičkih sistema“ koji pokazuju „ekstremnu osetljivost na početne uslove“11 (iako ostaju potpuno deterministički) ${ }^{12}$ - ona se često ilustruje konceptom „efekta leptira“, shvatanju da naizgled zanemarljiva promena, poput zamaha leptirovih krila, može hiljadama kilometara dalje i nedeljama kasnije da uzrokuje ogromne promene kao što je snažni nalet tornada. Prelaz sistema iz periodičnog linearnog takta (npr. obrtanja točka sa kofama pod mlazom vode 3,7 krugova u jednom smeru, a 2,6 u drugom) u aperiodični haotični režim (udvostručenjima obrtaja mlazom do trena kad točak gubi svaki ritam) preko kritične tačke „ivice haosa“, važan je ne samo kod analiza promenljivih „faza turbulencije“ (poput napada aritmije/epilepsije/grupne panike koji izbijaju naprasno, slično ključanju tečnosti), već i pri razumevanju povezanog fenomena teorije katastrofa - „bifurkacije“ tj. grananja sistema usled delovanja prejake sile njega, kao tipične odlike mnoštva bioloških organizama čiji život se odvija u stalnom prilagođavanju na neprikladne uslove (ali od početka određenom koordinatama odabranog

${ }^{11}$ Fraktali kao geometrijski objekti koji se protežu kroz izvesnu frakciju cele dimenzije i odlikuju svojstvima poput „samo-sličnosti“ i nezavisnosti ,ک̌uma“ od skale zumiranja (Mandelbrot 1982: 1-3) - nalik prirodnim objektima kao što su pahulje, oblaci ili munje - mogli bi, pored ostalog, objasniti i ekonomično kodiranje genetskih instrukcija za račvanje nerava (npr. uvek kad im dužina dođe do pet širina): pri tom bi i upotreba „,velikih podataka“, kao u slučaju genomike, stvorila put za novi „kvantitativni“ progres neuronauke (Sejnowski, Churchland \& Movshon 2014: 1440).

${ }^{12}$ Ako sistem „ne kruži ka startu“, opisiv je jedino računicom svih prethodnih stanja - ne i obrazaca ili verovatnoća. 
smera evolucije - kao što je npr. bilateralna simetrija uslov aerodinamičkih osobina).

Pod konceptom „emergencije“ podrazumeva se pak proces iskrsavanja viših ili složenijih odlika sistema kroz interakciju njegovih nižih ili prostijih elemenata, koji na bazi jednostavnih pravila odnošenja spram neposrednih suseda, mogu odozdo-nagore urediti „skokovitu promenu“ celog sistema: fenomeni kvantnog uplitanja, kristalizacije molekula, sinhronizacije roja insekata, jata ptica, gradskog saobraćaja, kondenzacija oblaka ili globalnog zagrevanja, neki su od primera sistema sa emergentnim odlikama koje prethodno ne ispoljavaju njihovi niži sastavni elementi - kao što, dakle, ni jedan od molekula vode nije mokar sam po sebi, već se data osobina javlja tek u jedinjenju koji oni sačinjavaju, ili što ni jedan mrav ne shvata složene autoregulativne funkcije kolonije čiji je pripadnik, već samo rutinski izvršava svoju skromnu ulogu u njoj, tako ni jedan od ljudskih neurona ne poseduje bilo kakvu svest ${ }^{13}$, nego se ona pojavljuje tek kao novi stadijum samoodnošenja čovekovog organizma (to što se njegov nervni sistem od najbližih vrsta razlikuje samo po još nekoliko ciklusa ćelijske reprodukcije, takođe svedoči o tome kako prilično minorne strukturne promene omogućavaju relativno velike funkcionalne specifičnosti tj. kreativne vidove upotrebe ljudskog nervnog sistema, kao npr. kad dvojica fokusiranih šahista dovedu organizme u slično fiziološko stanje kojim se jedinke srodnih vrsta odlikuju tokom neposredne fizičke borbe - gledano prema moždanim obrascima aktivnosti, nivou kataboličkih hormona ili srčanom pulsu). Čovekova sposobnost transponovanja sukoba iz realne u simboličku ravan, mogla bi takođe biti sagledana kroz prizmu emergentnog fenomena „kolektivne inteligencije“ tj.

${ }^{13}$ Ukazivanju Dejvida Čalmersa na „težak problem svesti“ tj. hipotetičku mogućnost „filozofskih zombija“ koji ne bi imali nikakve unutrašnje kvalitete iskustva, uprkos punoj biološkoj identičnosti sa ljudima, tokom poslednjih godina Đulio Tononi suprotstavio je „teoriju integrisane informacije“ koja preko formalizovanih postulata nastoji predvideti strukturnu meru svesnosti $\Phi$ za bilo koji sistem, kao „internu kauzalnu moć nad sobom“ (uključujući npr. i internet). 
„mudrosti gomila“614 (intelektualne nadmoći većeg agregata laičkih mišljenja nad manjim skupom ekspertskih sudova, npr. veće ažurnosti Vikipedije spram Enciklopedije Britanike, kao efektu kolaborativnog procesa usmerenog prema stalnom uzajamnom korigovanju, poništavanju i filtriranju nizova informacija) imajući u vidu i oživele naznake vere u zamenu državnih udara mirnim „plišanim revolucijama“ - pri kojim se potreba za realnim nasilnim delovanjem ukida na račun simboličke demonstracije masovnosti samo-organizovanih pokreta, iako se isti princip može uvideti već kod onlajn peticija ili grasruts inicijativa na društvenim medijima ${ }^{15}$ - zbog čega bi se pomoću digitalnih tehnologija mogli bitno osnažiti i autokorektivni mehanizmi planetarno uzdrmanog demokratskog poretka, ${ }^{16}$ u meri uviđanja da njima svojstvenu inkluzivnost i diverzitet mišljenja ne bi trebalo tretirati samo poput „šuma u komunikativnom protokolu“ tj. sistemske greške koju treba intenzivno redukovati umanjivanjem nepreciznosti opservacija, nego da bi se i simptomi ere ,post-istine“ takođe mogli anulirati kroz

${ }^{14}$ Čiji se devalviran status u poređenju s fahovsko-specijalističkim znanjem pokazuje i na primeru obrnute percepcije isplativosti pomoći prijatelja spram pomoći publike u kvizu „Želite li da postanete milioner“ (Surowiecki 2004: 2-3) - pri tom je neretko, kao i kod istraživanja javnog mnjenja putem „fokus grupa“, bitniji diverzitet od veličine uzorka (s tim u vezi shvatljivi su npr. i masovni onlajn sistemi filmskih preporuka čiji kvaliteti potiskuju „elitne kritičare“). Analitika „prediktivnih tržišta“ (npr. procena izbora ili decentralizovanih kriptovaluta) uz to bi mogla imati efekte na razvoj analognih modela „plebiscitarnih aktivnosti“ neuronskih populacija tj. empirijskih priloga teoriji odlučivanja.

${ }^{15}$ Impuls neurofilozofskom relativizovanju jaza digitalnog i realnog sveta pružio je i razvoj koncepta „self-modela“, koji sugeriše da sopstvo nije stvar, već proces u kome se čovek iznova identifikuje sa dinamičnim avatarom, ali zbog nevidljivosti toka njegove konstrukcije, ostaje u iluziji da je „beskonačno blizu samom sebi“" (slično tome kada bi se identifikovao sa strelicom kompjutera, posle dužeg perioda koncentracije na poteze sa njom (Metzinger 2009 : 3-4)).

${ }^{16}$ Što evocira i sumorni podatak da je prosečna inteligencija vrste ipak obrnuto srazmerna vremenu njenog opstanka (time se iz ugla teorije igara ističe i kooperativna/simbiotička naspram kompetitivne/antagonističke vizije evolucije). 
ekstenzivno usložnjavanje tj. iscrpno međusobno prepravljanje ljudskih gledišta. ${ }^{17}$ Poređenja koja ukazuju kako standardni projekcioni profili neurona i geografske lokacije kontakata na društvenim medijima mahom slede „distribuciju zakona potencije“ tj. pravilo 80/20, u pogledu srazmere bliskih „rutinsko-operativnih“ i udaljenih „kreativnointegrativnih" relacija ${ }^{18}$ - slično odnosu vremenske učestalosti i fizičkog intenziteta zemljotresa, ili kategorije prihoda i udela državnog stanovništva koji ih ostvaruje (Sapolsky 2010: 1:17:58) - išla bi u prilog ne samo zaključku da „optimalna konektivnost“ elemenata tj. aktera mreže koja isključuje sheme kontrole odozgo-nadole, može biti jedino rezultat minimuma njihove apriorne funkcionalne određenosti, obrnuto proporcionalne mogućoj strukturnoj kompleksnosti novonastajućeg adaptivnog sistema ${ }^{19}$ - već bi i uvid da je ,interakcija plodnija što su

17 To se da potkrepiti i primerom, ,inteligencije rojeva“: bilo da se radi o „pčelinjem plesu“, čije trajanje progresivno uvećava šanse da najbolji izvor resursa bude ispitivan od što većeg broja ostalih jedinki, bilo o mravljem feromonu, čijim brzim isparavanjem po ispuštanju raste verovatnoća da će samo najdeblji tragovi - tj. najkraće putanje između mnoštva lokacija - opstati „posle rada lutajućih mrava" tj. tragalaca tragova koji ih uvek obnavljaju kad naiđu na njih (pa se datom „optimizacijom“ rešava $i$,problem trgovačkog putnika“ $t j$. najbolje rute između velike mreže gradova) - suština je da se „pozitivan signal“ vremenom pojačava upravo sa rastom faktora slučajnosti u fazi „randomizacije“, pri čemu se globalni obrazac kristalizuje isključivo lokalnim pravilima atrakcije i repulzije (,sviđanja i nesviđanja“).

${ }^{18}$ Odstupanje od toga postoji kod osoba sa autizmom, čime se objašnjava slabija funkcionalna integracija ponašanja. Suprotno usmerenu odredbu šizofrenije, koja implicira „abnormalnu širinu kognitivnih asocijacija“, Robert Sapoljski pak tumači i kroz pozitivan bilans ,šamanističkog“ tipa šizoidnosti, oličenog u raznim civilizacijskim varijetetima ,iscrpljujuće komunikacije sa onostranim“, čija je istorijska sublimacija iznedrila genije moderne nauke i umetnosti.

${ }^{19}$ Premrežavanje mnoštva uzajamno iniciranih ličnih kontakata na društvenim medijima jednim brojem naloga koji bivaju vezani za velike sisteme javnog informisanja, kao i gravitiranje inače haotičnih putanja neuronskih sinapsi ka razvoju projekcija uz radijalne glije (u embrionalnoj fazi), prolazi sličan „luk“ iskrsavanja komunikativnih struktura - uz oba slučaja vezuje se i „topologija malog sveta“ $t \mathrm{t}$. „povezivost bilo kojih čvorova velike mreže u malo koraka“. 
pravila prostija“ ${ }^{620}$ markirao efektivni paralelizam mozga i interneta: tim se pak sugeriše obrt u regulaciji odnosa novih i tradicionalnih medija, ali i edukativnih modela - tj. inverzija statusa ,personalnoistraživačkih“ i „socijalno-orijentacijskih“ aspekata komunikacije utoliko što bi ona tad povlačila efikasniji angažman kognitivnih resursa čoveka u konvulzivnim vremenima ,antropocena“ tj. „,neočekivanog kraja epohe predvidivosti“. Ipak, eminentni fizičar kompleksnih sistema Džordž Elis takođe bi mogao imati pravo kad uviđa da infrastrukture globalne mreže i višećelijskih organizama uz sve materijalne/energetske razlike otvaraju prostor za iskrsavanje kauzalnih relacija ne samo odozdo-nagore, već i odozgo-nadole (pa tako nasuprot peščanih dina, svemirske letelice iziskuju udružene planove mnoštva profesija) - što uz vremenska određenja početnog i krajnjeg delovanja zaokružuje Aristotelov četvorostruki koncept uzroka (Ellis 2008: 70) - produktivne niti preplitanja neurofilozofije i društvenih medija mogle bi sinergijom „generalizacijskih i specijalizacijskih potencijala“ komunikativnih zajednica doprineti analognom pluralizovanju savremenih društvenotehničkih matrica teorijskog života.

\section{LITERATURA}

Basset, D. S. and Sporns, O. (2017). "Network Neuroscience" in: Nature Neuroscience, 20: 353-364

Chomsky, Noam (1957). Syntactic Structures. The Hague: Mouton

${ }^{20}$ Čuveni zastupnik teze da „kvantitet produkuje kvalitet“, koju je i Gari Kasparov izneo po gubitku šahovske partije od $I B M$-ovog superkompjutera Deep Blue, danas u anglofonim univerzitetskim krugovima često figurira i kao junak ironične izreke: ,ako izučavate Hegela, to je germanistika, ako izučavate kičmenu moždinu pacova, to je filozofija“. Ipak, neke od prvih mostova humanističkih i kibernetičkih pristupa još pre više decenija inicirali su i mislioci poput Gotarda Gintera, ,polivalentno-logičkom“ operacionalizacijom formalnog sistema dijalektike apsolutnog idealizma, a njen duh je reaktuelizovala i Katrin Malabu kroz „eksplozivne“ impulse preobličavanja ideje ,(neuro)plastičnosti“: suprotno ustrojstvima „telefonskih centrala“ ili „delokalizovanih korporacija“ za mozak je očito vitalna ,sila otpora“. 
Churchland, Patricia S. (1986). Neurophilosophy: Toward a Unified Science of the Mind-Brain. Cambridge: Bradford Books

Churchland, Paul M. (1989). A Neurocomputational Perspective: The Nature of Mind and the Structure of Science. Cambridge: Bradford Books

Dreyfus, Hubert (2001). On the Internet. New York: Routledge.

Ellis, G. F. R. (2008). "On the Nature of Causality in Complex Systems" in: Transactions of the Royal Society of South Africa, 63 (1): 69-84

Hofstadter, Douglas (1979). Gödel, Escher, Bach: an Eternal Golden Braid. New York: Basic Books

Mandelbrot, Benoit B. (1982). Fractal Geometry of Nature. New York: Times Books

Meshi, D., Tamir, D. and Heekeren, H. (2015). „The Emerging Neuroscience of Social Media" in: Trends in Cognitive Sciences, 19 (12): 771-782

Metzinger, Thomas (2009). The Ego Tunnel: The Science of the Mind and the Myth of the Self. New York: Basic Books

Pinker, Stiven (2003). The Blank Slate: The Modern Denial of Human Nature. New York: Penguin Books

Sapolski, Robert (21.5.2010). "Emergence and Complexity". Retrieved 3.12. 2018. „URL: $<$ https://www.courses.com/stanford-university/humanbehavioral-biology/22>

Sejnowski, T. J., Churchland, P. S. \& Movshon, J. A. (2014). "Putting big data to good use in neuroscience" in: Nature Neuroscience, 17: 1440-1441

Surowiecki, James (2004). The Wisdom of Crowds. New York: Doubleday.

Tagard, Pol (2014). Mozak i smisao života. Novi Sad: Akademska knjiga

\author{
MILAN VUKADINOVIĆ \\ University of Novi Sad, Faculty of Philosophy
}

\title{
NEUROPHILOSOPHY AND SOCIAL MEDIA: INTERMESHING OF COMPLEX NETWORKS
}

\begin{abstract}
A neuroscientific progress during the last couple of decades has not only gradually revealed human brain as a „social organ“ which evolved to connect with the other brains, but has also raised the possibilities of wider neurophilosophical approach to a sphere of contemporary social phenomena such as increasing human interaction on a social media enabled by new digital technologies. Not only that neurophilosophy could provide an empirical basis for more objective considerations of complex existential, cultural, political and ethical aspects of human society in the present stage of global interconnectedness, but even some of the newer approaches from the anti-reductionist end of the spectrum of „behavioral and brain sciences“ (such as theories of chaotic or emergent dynamical systems) could be rendered useful in researching complex networks
\end{abstract}


of social interaction, which may have a significant effect on strengthening democratic phenomena such as the „wisdom of crowds“, grassroot initiatives or velvet revolutions.

Keywords: neurophilosophy, social media, cognitive science, chaotic complex networks, wisdom of crowds

Primljeno: 26.12.2018.

Prihvaćeno: 15.2.2019. 